Abstract P281 Table 1 showing mean baseline lung function and annual decline. All values are expressed as percentages and based on predicted values for age, weight and sex (percentage predicted values). Ranges are in brackets.

\begin{tabular}{|c|c|c|c|c|c|c|c|c|c|c|}
\hline & $\begin{array}{l}\text { Baseline } \\
\text { FEV1 }\end{array}$ & $\begin{array}{l}\text { FEV1 annual } \\
\text { change }\end{array}$ & $\begin{array}{l}\text { Baseline } \\
\text { FVC }\end{array}$ & $\begin{array}{l}\text { FVC annual } \\
\text { change }\end{array}$ & $\begin{array}{l}\text { Baseline } \\
\text { vC }\end{array}$ & $\begin{array}{l}\text { VC annual } \\
\text { change }\end{array}$ & $\begin{array}{l}\text { Baseline } \\
\text { TLC }\end{array}$ & $\begin{array}{l}\text { TLC annual } \\
\text { change }\end{array}$ & $\begin{array}{l}\text { Baseline } \\
\text { KCO }\end{array}$ & $\begin{array}{l}\text { KCO annual } \\
\text { change }\end{array}$ \\
\hline $\begin{array}{l}\text { Whole population } \\
(n=48)\end{array}$ & $\begin{array}{l}89.4(51.0- \\
136)\end{array}$ & -0.2 & $\begin{array}{l}96.7 \\
(47.0- \\
139.0)\end{array}$ & -1.0 & $\begin{array}{l}94.9 \\
(51.0-134)\end{array}$ & -0.7 & $\begin{array}{l}77.5 \\
(44.0-121.0)\end{array}$ & -2.0 & $\begin{array}{l}94.6 \\
(49.0-135- \\
.0)\end{array}$ & -2.5 \\
\hline $\begin{array}{l}\text { Lifelong non } \\
\text { smoker } \\
(n=6)\end{array}$ & $\begin{array}{l}105.8 \\
(77.0-36.0)\end{array}$ & -1.2 & $\begin{array}{l}108.7 \\
(91.0- \\
139.0)\end{array}$ & -2.5 & $\begin{array}{l}105.0 \\
(94.0- \\
134.0)\end{array}$ & -2.32 & $\begin{array}{l}83.2 \\
(64.0-100.0)\end{array}$ & -4.9 & $\begin{array}{l}106.5 \\
(90.0-130.0)\end{array}$ & -3.9 \\
\hline $\begin{array}{l}\text { Ex smoker } \\
<20 \text { pack years } \\
(\mathrm{n}=13)\end{array}$ & $\begin{array}{l}91.9 \\
(51.0-133.0)\end{array}$ & -1.8 & $\begin{array}{l}93.8 \\
(54.0- \\
133.0)\end{array}$ & -2.8 & $\begin{array}{l}90.4 \\
(51.0-127)\end{array}$ & -2.61 & $\begin{array}{l}70.1 \\
(44.0-88.0)\end{array}$ & -1.1 & $\begin{array}{l}109.2 \\
(78.0-135.0)\end{array}$ & -7.2 \\
\hline $\begin{array}{l}\text { Ex smoker } \\
20-40 \text { pack years } \\
(\mathrm{n}=16)\end{array}$ & $\begin{array}{l}96.0 \\
(69.0-125.0)\end{array}$ & 0.0 & $\begin{array}{l}103.8 \\
(67.0- \\
134.0)\end{array}$ & -1.2 & $\begin{array}{l}99.9 \\
(65.0- \\
125.0)\end{array}$ & -0.2 & $\begin{array}{l}83.9 \\
(53.0-121.0)\end{array}$ & -3.5 & $\begin{array}{l}95.6 \\
(70.0-147.0)\end{array}$ & -1.0 \\
\hline $\begin{array}{l}\text { Ex smoker } \\
>40 \text { pack years } \\
(n=9)\end{array}$ & $\begin{array}{l}67.5 \\
(53.0-98.0)\end{array}$ & +1.0 & $\begin{array}{l}80.3 \\
(47.0- \\
107.0)\end{array}$ & +1.0 & $\begin{array}{l}81.9 \\
(57.0- \\
108.0)\end{array}$ & +0.7 & $\begin{array}{l}70.8 \\
(48.0-98.0)\end{array}$ & +1.9 & $\begin{array}{l}78.4 \\
(57.0-112.0)\end{array}$ & -1.4 \\
\hline $\begin{array}{l}\text { Current smoker } \\
(\mathrm{n}=4) \\
>40 \text { pack years }\end{array}$ & $\begin{array}{l}80.0 \\
(72.0-86.0)\end{array}$ & +1.01 & $\begin{array}{l}97.0 \\
(84.0- \\
109.0)\end{array}$ & +1.75 & $\begin{array}{l}102.0 \\
(88.0- \\
115.0)\end{array}$ & +0.18 & $\begin{array}{l}\text { Not } \\
\text { calculated }\end{array}$ & Not calculated & $\begin{array}{l}68.5 \\
(49.0-109.0)\end{array}$ & -2.39 \\
\hline
\end{tabular}

Abstract P282 Table 1 Demographic data of the analysed cohort 132 patients with IPF, showing the proportional variation across the 3 prediction equations for determining eligibility for anti-fibrotic treatments using NICE cut-off ranges. Data are presented as mean values with standard deviations in parentheses

\begin{tabular}{ll}
\hline Age (years) & $\mathbf{7 2 . 4}(8.3)$ \\
\hline M:F & $100: 32$ \\
FVC (L) & $2.7(0.8)$ \\
Mean FVC\% Predicted ECCS & $80.6(19.8)$ \\
Number of Patients with FVC 50-80\% ECCS & 66 \\
FVC\% Predicted NHANES III & $74.2(17.1)$ \\
Number of Patients with FVC 50-80\% NHANES III & 80 \\
FVC\% Predicted GLI & $75.6(17.3)$ \\
Number of Patients with FVC 50-80\% GLI & 78 \\
\hline
\end{tabular}

Conclusions Using ECCS, 50\% of patients met the NICE criteria for anti-fibrotic treatment. When NHANES III and GLI are used, patient eligibility for treatment increases to $61 \%$ and 59\% respectively. Interestingly both the NHANES and GLI equations decrease the $\%$ predicted, and those patients that are just above the $80 \%$ cut off when ECCS is used become eligible for treatment just by using alternative prediction equations. The NICE Guidance does not specify which equation to use when assessing patients; in our patient cohort, the NHANES III or GLI would allow more patients to meet NICE eligibility for treatment. These data question, the use of predictive FVC cut-offs in prescribing anti-fibrotic treatments in a progressive lung disease without providing a national reference standard, especially when the particular prediction equation used could significantly impact on patients' eligibility for treatment.

\section{P283 AN ELEVATED PEF/FVC RATIO IS A MARKER FOR ILD AND IS ASSOCIATED WITH TRACTION BRONCHIECTASIS ON CT SCAN IMAGING}

K Cranstone, J Briggs, J Park, T Nicholson, M Unstead. Royal Berkshire NHS Foundation Trust, Reading, UK

\subsection{6/thoraxjnl-2016-209333.426}

Introduction ILD is physiologically characterised by restrictive ventilatory pattern, impaired gas exchange, maintained airway patency and increased elastic lung recoil pressure. Spirometric values are often well-preserved but the shape of the flow volume (FVL) can suggest enhanced mechanical emptying of the lungs. Previously spirometry has identified upper airways obstruction, ${ }^{1}$ but limited data exists for the use of an index to describe possible ILD.

Method Retrospective PFT data was analysed ( $\mathrm{n}=119)$. The slope of the line from PEF to RV (PEF/FVC ratio) was calculated and correlated against other PFT variables. Pearson's correlation was applied between the ratio and markers of ILD, data from table previously presented at the ARPT conference 2015*. 30 patients $(27 \hat{\partial}, 3$ ) $)$ were selected for CT analysis and qualitative verification of Traction Bronchiectasis (TBX). CT scan had to be within 6 months of PFTs, FVC $>70 \%$ predicted and a PEF/ FVC $>2.0$ (range 2.11-4.36). Information on location within the lung and level of severity was obtained.

Results Of the 30 patients, 27 were found to have TBX, $(3$ mild, 17 moderate and 8 severe), 3 patients had no evidence of TBX. No correlation was found between magnitude of PEF/FVC and severity of TBX. 


\begin{tabular}{|c|c|c|c|c|c|c|}
\hline $\begin{array}{l}\text { Demographics } \\
\begin{aligned} \mathrm{N} & =119 \\
\hat{C} & =37 \\
& =82\end{aligned}\end{array}$ & $\begin{array}{l}\text { PEF/FVC } \\
\text { (mean } \\
\pm \text { SD) }\end{array}$ & $\begin{array}{l}\text { PEF/FVC } \\
\% \text { Pred } \\
\text { (mean } \pm \\
\text { SD) }\end{array}$ & $\begin{array}{l}\text { Dependant } \\
\text { Variable }\end{array}$ & $\begin{array}{l}\text { Independent } \\
\text { Variable }\end{array}$ & $\begin{array}{l}\text { R } \\
\text { (Pearson's) }\end{array}$ & $\mathrm{R}^{2}$ \\
\hline $\begin{array}{l}\text { ILD } \\
\mathrm{n}=96\end{array}$ & $\begin{array}{l}2.96 \\
(0.65) \\
\dagger+\end{array}$ & $\begin{array}{l}136.15 \\
(31.42)\end{array}$ & $\mathrm{PEF} / \mathrm{FVC}$ & TLC (\%) & -0.792 & 0.63 \\
\hline $\begin{array}{l}\text { Obstructive } \\
\mathrm{n}=16\end{array}$ & $\begin{array}{l}1.13 \\
(0.30)^{*}\end{array}$ & $\begin{array}{l}59.90 \\
(9.41)\end{array}$ & PEF/FVC & RV (\%) & -0.759 & 0.58 \\
\hline $\begin{array}{l}\text { Normal } \\
\mathrm{n}=7\end{array}$ & $\begin{array}{l}1.96 \\
(0.26)\end{array}$ & $\begin{array}{l}91.20 \\
(9.18)\end{array}$ & PEF/FVC & VA (\%) & -0.665 & 0.44 \\
\hline
\end{tabular}

$\dagger p<0.01$ ILD vs COPD, $₫<0.01$ ILD vs Normal, ${ }^{*} p<0.01$ COPD vs Normal.

Conclusion Structural changes from TBX may cause stenting of the airways from fibrotic tissue, holding them open during forced expiration. ${ }^{2}$ Our volume corrected PEF/FVC predicts reduced TLC and RV percent predicted, indicating reduced lung volumes and lung stiffness in patients with restrictive lung disease. The evidence of TBX on CT imaging supports the hypothesis that airways are held open during forced expiration, allowing increased efficiency of lung emptying in patients with a PEF/FVC >2.0. The magnitude of the ratio did not correlate with TBX severity but further work to determine a cut off ratio to predict future fibrosis is required. This index may be of use indicate a value beyond which TBX is likely to be present.

\section{REFERENCE}

1 Empey DW. Assessment of upper airway obstruction. BMJ 1972;3:503-505.

2 Woodring JH, Barrett PA, Rehm SR, et al. Acquired tracheomegaly in adults as a complication of diffuse pulmonary fibrosis. AJR 1989;152(4):743-747.

\section{P284 IDENTIFYING PATIENTS AT RISK OF ACUTE EXACERBATION OF IPF USING THE CPI SCORE}

${ }^{1}$ E Fraser, ${ }^{2} V$ St Noble, ${ }^{2} \mathrm{R}$ Benamore, ${ }^{3} \mathrm{R}$ Hoyles, ${ }^{1} \mathrm{LP}$ Ho. ${ }^{1} \mathrm{M} R \mathrm{C}$ Human Immunology Unit, Weatherall Institute of Molecular Medicine, University of Oxford and Oxford Interstitial Lung Disease Service., Oxford, UK; ${ }^{2}$ Thoracic Imaging Department, Oxford University Hospital NHS Trust, Oxford, UK; ${ }^{3}$ Oxford Interstitial Lung Disease Service, OUH NHS FoundationTrust, Oxford, UK

\subsection{6/thoraxjnl-2016-209333.427}

Introduction Disease course in IPF is punctuated by acute declines, often termed acute exacerbations of IPF (AEIPF) and portends to a mortality of $80 \%$ within 3 months. The cause of AEIPF is poorly understood; and there is currently no effective treatment. There is an urgent need to understand the causes and to characterise the parameters that identify patients at risk of AEIPF. Because lung function (DLCO and FVC) and CT imaging are the most accessible (potential) methods for identification of patients at risk of AEIPF, we question if these could be used to identify patient at risk of AEIPF. We explored the utility of the $\mathrm{CPI}^{1}$ (composite physiological index) for this purpose.

Methods Patients with IPF diagnosed by clinico-pathologic-radiological criteria, according to the 2011 ATS/ERS/JRS/ALAT guidelines, with definite or probable diagnosis of IPF were recruited over a one year period, and divided into stable $(n=12)$ and AEIPF $(n=8)$ groups. AEIPF was defined as: 1$)$ deterioration in dyspnoea over 30 days or less 2) new airspace infiltrates on HRCT (with or without evidence of infection) 3) exclusion of pulmonary emboli and heart failure. Lung function (FVC and DLCO) and CPI at 12 months before recruitment and rate of change of FVC within these 12 months were determined.

Results and discussion Patients with AE-IPF had a significantly higher CPI; (mean $\pm \mathrm{SD}$ ) $-62 \pm 13$ vs stable $45 \pm 7$; $\mathrm{p}=0.001$. In contrast, there was no significant difference in FVC levels between the two groups $-61 \pm 4 \%$ predicted in AEIPF group vs $72 \pm 3 \%$ in stable; $p=0.07$. CPI but not FVC or DLCO was worse 12 months prior to recruitment in the AEIPF group. Rate of loss in FVC in the year before AEIPF was not significantly different from those with stable disease

Conclusions Early findings suggest that in contrast to DLCO and FVC, high CPI is associated with occurrence of AEIPF within a year. Rate of FVC loss did not correlate with AEIPF in this small study. CPI could be a more sensitive predictor for AEIPF than FVC and DLCO but larger numbers and a prospective study will be required to test this concept.

\section{REFERENCE}

1 Wells AU. AJRCCM 2003.

\section{Drugs and Devices in COPD}

\section{P285 THE 'REAL-LIFE' COPD PATIENT IN THE AGE OF LABA/ LAMAS: AN EXPANSION OF THE DACCORD STUDY}

${ }^{1} \mathrm{C}$ Vogelmeier, ${ }^{2} \mathrm{H}$ Worth, ${ }^{3} \mathrm{R}$ Buhl, ${ }^{4} \mathrm{CP}$ Criée, ${ }^{5} \mathrm{C}$ Mailaender, ${ }^{5} \mathrm{~N}$ Lossi, ${ }^{6} \mathrm{P}$ Kardos. ${ }^{1}$ Department of Medicine, Pulmonary and Critical Care Medicine, University Medical Centre Giessen and Marburg, Philipps University Marburg, Member of the German Centre for Lung Research (DZL), Marburg, Germany; ${ }^{2}$ Facharztforum Fürth, Fürth, Germany; ${ }^{3}$ Pulmonary Department, Mainz University Hospital, Mainz, Germany; ${ }^{4}$ Department of Sleep and Respiratory Medicine, Evangelical Hospital Goettingen-Weende, Bovenden, Germany; ${ }^{5}$ Novartis Pharma GmbH, Nürnberg, Germany; ${ }^{6}$ Group Practice and Centre for Allergy, Respiratory and Sleep Medicine, Red Cross Maingau Hospital, Frankfurt, Germany

\subsection{6/thoraxjnl-2016-209333.428}

Introduction The prospective, non-interventional DACCORD study collects data from a representative cohort of COPD outpatients across Germany who either initiated or changed COPD maintenance medication prior to entry. Initially, DACCORD consisted of two treatment groups (Glycopyrronium-based therapy vs. any other COPD maintenance medication with the exception of Glycopyrronium). Following the approval of LABA/LAMA fixed-dose combinations (FDC) in 2013, DACCORD was extended to follow an additional cohort of patients receiving any LABA/LAMA FDC over a period of 2 years.

Methods 5223 patients with complete baseline data (3815 LAMA/LABA FDC vs. 1408 standard treatment group) were analysed here. Baseline exacerbations were evaluated 6 months prior to study entry and were annualised for GOLD 2011 categorization; COPD symptoms were evaluated using the COPD Assessment Test (CAT) and the mMRC questionnaire. Prior and concomitant COPD medication were captured and analysed by substance class.

Results Baseline characteristics are summarised in Table 1. Based on FEV1 assessment, approx. 75\% of patients suffered from moderate to severe COPD. Less than a quarter of patients reported a history of exacerbations and only $6.7 \%$ experienced $\geq 2$ exacerbations in the 6 months prior to study 